\title{
Analysis of Mathematics Literation Ability of Students in Completing PISA-Oriented Mathematics Problems with Changes and Relationships Content
}

\author{
Budi Murtiyasa, Wulan Rahma Galuh Perwita* \\ Department of Mathematics Education, Faculty of Teacher Training and Education, Universitas Muhammadiyah Surakarta, Indonesia
}

Received April 27, 2020; Revised May 23, 2020; Accepted June 23, 2020

Copyright $@ 2020$ by authors, all rights reserved. Authors agree that this article remains permanently open access under the terms of the Creative Commons Attribution License 4.0 International License

\begin{abstract}
Mathematical literacy in Indonesia has until now become a major problem in the study of international PISA surveys. This study aims to describe the abilities of students' mathematical literacy in solving PISA-oriented problems with change and relationship content. This work is descriptive qualitative research. Data collection techniques include tests, interviews and documentation. Data analysis techniques in this study are carried out with three activities namely reducing data, presenting data, and drawing conclusions. To ensure the validity of the data, triangulation technique is used. The research subjects are 31 middle school students of year 9 . Based on the analysis of students' abilities by using average calculations and standard deviations, it is obtained that the student ability could be categorized into high, medium, and low ability. The results show that for the five abilities in the process of mathematical literacy, most students had communication skills. However, they have lower ability in mathematical, reasoning and argument, as well as identifying and determining strategies for solving the problems.
\end{abstract}

Keywords Mathematical Literacy, PISA, Change and Relationship

\section{Introduction}

Education is the most important learning that is carried out by everyone from one generation to the next through teaching, training or research with the aim of being able to educate and develop the potential within learners. Based on the educational law of Republic of Indonesia No. 20 year 2003 Article no. 1 concerning the National Education System, education is a conscious and planned effort to create an atmosphere of learning and learning process so that students actively develop their potential to have spiritual strength, self-control, personality, intelligence, noble character, and the skills they need for theirself, society, nation and state.

According to Hans Freudental (in Sudarwan Dani, 2012), mathematics is a human activity and must be linked to the reality. Thus, mathematics is a way of thinking logically that is represented in numbers, spaces, and forms with existing rules that cannot be separated from these human activities. In essence, mathematics is inseparable from daily life. All life problems that require careful and meticulous solutions inevitably require mathematical assistance. Many factors must be considered in learning mathematics, including the willingness, ability and certain intelligence, teacher readiness, student readiness, curriculum and presentation methods.

The Indonesian government views the importance of solving problems in learning mathematics. Arseven (2015) says that using models in teaching mathematics is needed to motivate students, eliminate their fears and anxieties. This is also crucial to possibly develop a positive approach to mathematics besides it has many cognitive benefits such as realizing meaningful learning, building relationships between mathematics and daily life and develop problem solving skills. Although Indonesia has formally placed its mathematical problem-solving skills as one of the main goals of mathematics learning, in the tests conducted by the Program for International Student Assessment (PISA), the Indonesian students have not shown satisfactory achievement. None of Indonesian students have reached the highest level of 6 for PISA questions. The PISA questions are developed based on 4 contents which are: (1) Space and Shape, (2) Change and Relationship, (3) Quantity, and (4) Uncertainty and Data.

According to the 2015 PISA surveys under the Organization for Economic Cooperation and Development 
(OECD) students' mathematical abilities in Indonesia rank $63^{\text {rd }}$ out of 69 countries. This means that there are still many students who have difficulty in completing PISA math problems. The low rank of Indonesian students' mathematical abilities in the PISA survey shows that students in Indonesia are still low in their mathematical abilities in terms of their mastery of the material. Murtiyasa, et al (2018) in their research stated that the use of problems in accordance with PISA framework can stimulate students 'critical thinking skills and students' mathematical communication.

One of the factors causing low PISA results is that the students have not been trained in solving PISA problems. This can be seen from their strategies and explanations in solving PISA questions (Novita and Putra, 2016). Another indication that the mathematical literacy ability of students in Indonesia is still low, is shown by the fact that the ability of Indonesian students to always be ranked in the 10 lowest countries. In the results of the PISA study, the average international score on mathematics literacy ability is 500 (level 3), while the average mathematics literacy score of Indonesian students is 375 (level 1), level 1 is the lowest level of the six level of mathematical literacy ability set by PISA. The highest level reached by Indonesian students was level 3 (OECD, 2017). Mathematical literacy is the ability of individuals to formulate, use, and interpret mathematics in various contexts. Including mathematical reasoning and the use of concepts, procedures, facts, and mathematical tools to describe, explain, and predict phenomena as well as helping individuals to recognize the role of mathematics in the world and make judgments and decisions taken by students' construction, involvement and reflection (OECD, 2010). In his research, Ojose (2011) stated that Mathematical literacy is a problem in society even though mathematical literacy is needed both at work and in everyday life. Mathematical literacy is one of the keys to anticipate a changing society because it is as important as proficiency in reading and writing.

The competencies needed for mathematics literacy are described in the work of the PISA under the auspices of OECD and are in line with description by Steen (2001). The competencies are mathematics thinking and reasoning, mathematical argumentation, mathematical communication, modeling, problem posing and solving, representations, symbols, and tools and technology. According to Nizar and Putri (2018), aspects of mathematical literacy abilities that often arise are communication and representation. Communication skills are demonstrated by the ability of students to write the process of achieving solutions and inferring mathematical results. The ability of representation is shown by the ability of students who use various representations in problem solving. Wijaya (2016) stated that to investigate information on student literacy, the analysis focuses on responses that contain common errors. There are three types of common errors namely misunderstanding, errors in instructions, and errors in choosing information.

Rusmining, et al. (2014) reveals that teachers must give students reasoning, argumentation, and problem solving skills, so that students' mathematical literacy skills reach a maximum level. It is recommended for teachers and students to use question mathematics based on US PISA framework to practice their mathematical literacy skills. Due to the low level of PISA assessment result, education in Indonesia has to find solutions in order to improve the level. Wuli, et al. (2016) recommends that teachers and other practitioners use studies as a tool in designing PISA problem-based learning. Murdaningsih and Murtiyasa (2016) in their research at one of state middle school at Rembang Central Java state that the contents of 2013 curriculum book (K-13) have been in accordance with to the PISA component. The results of his research show that in the second semester of student books, problems involving the process of using mathematical concepts, facts, procedures, and reasoning are more dominant than others. In addition, the context is dominated by personal context. Furthermore, the first semester student books are dominated by change and relationships content, while the second semester books are dominated by space and shape content. Thus, schools that have used the 2013 curriculum and teachers as facilitators can adjust their teaching method in the classroom for learning mathematics based on PISA completion processes such as arguing, communicating, reasoning, and using problem solving strategies. Lin and Tai (2015) concluded that learning strategies affect mathematics literacy and the two are interrelated.

According to Ahyan, et al. (2014), mathematical problems based on PISA content of change and relationships have a potential effect on students. Mathematical skills for content of quantity and uncertainty are in the low category, while for change and relationship content, space and shape content are very low. Based on these results further research is needed to see why students have low skills in solving problems based on PISA framework or similar research for the other areas. Besides that, Nidya \& Jailani (2018) state from the results of their study that students must improve their mathematical skills to formulate mathematical situations, solve reasoning problems, interpret and evaluate arguments.

\section{Methods}

This study is a qualitative research with a qualitative descriptive approach because researchers want to describe or describe facts or circumstances that appear in students' mathematical literacy skills in solving PISA problems. This research is conducted at one of state middle school at Kartasura, Sukoharjo, Central Java, Indonesia. The subjects of this study are 31 students of year 9. The subject is chosen because PISA tests are intended for students aged 15 years. In Indonesia, 15 year old students are generally in 
ninth grade (year 9).

The data is obtained from the results of the work on the PISA test of change and relationship content by the students based on indicators of mathematical literacy abilities, namely communication skills, mathematical abilities, abilities to determine the strategy for solving the problem, argument ability and giving reasoning and abilities of using symbol operations and languages including formal languages, and technical languages as well as journals and books, concerning the ability of mathematical literacy based on PISA content change and relationship. Sources of data in this study are obtained from students, teachers, journals and books supporting basic data.

Data collection techniques include tests, interviews and documentation. In this study, questions are tested on students taken from A Question of Difficulty: Questions from PISA 2003 and the results of the study of Setiawan et al (2014), so that reliability and validity tests are not carried out because they are in accordance with PISA standards and test questions as well used to collect data about students' mathematical literacy skills in solving PISA questions. The interview is used to gather additional information related to the tests that have been conducted and the documentation consists of photos of the research process, student test results, and interview results. To ensure the validity of the data, triangulation of techniques are used which include observation, in-depth interviews, and documentation. The three processes are to get data from different sources by the same technique. Observation is used by researchers to observe the conditions of students and to compare student test results by analyzing, which then followed by in-depth interviews about the results of students' answers. Documentation is needed for data sources in the form of questions taken from PISA and in the form of a number of photographs as evidence that the researchers conducted real research.

The data analysis technique in this study is carried out by conducting three activities namely reducing data, presenting data, and drawing conclusions. Data reduction aims to simplify the data and to simplify understanding of the data that has been collected from student test results and interviews so that the reduced data gives a more detailed picture. Presentation of the data is to present the data obtained from the results of mathematical literacy skills by describing student test results. Conclusion is the final stage in the research process to draw conclusions on the results of student tests that have been analyzed.

\section{Discussion}

To analyze the results, the ability of 31 students in solving the problems is categorized into three different levels; high, medium, and low (Arikunto, 2012: 298). Student ability categories is determined in Table 1 as follows.

Table 1. Categories of Student Ability Levels

\begin{tabular}{cccc}
\hline Score & f & Percentage & Category \\
\hline $\mathbf{X}>\mathbf{8 3}$ & 7 & $22.58 \%$ & High \\
$\mathbf{4 6}<\mathbf{X} \leq \mathbf{8 3}$ & 16 & $51.61 \%$ & Medium \\
$\mathbf{X} \leq \mathbf{4 6}$ & 8 & $25.81 \%$ & Low \\
Total & 31 & $100 \%$ & \\
\hline
\end{tabular}

Table 1 shows the students ability levels using averages and standard deviations (Arikunto, 2012: 299). It is obtained that students who have high abilities are 7 students with a percentage of $22.58 \%$. Student with medium abilities are 16 students with a percentage of $51.61 \%$. In addition, low abilities students as many as 8 students are identified with a percentage of $25.81 \%$.

Table 2. Student Completion Abilities by Level

\begin{tabular}{cccc}
\hline Level & Frequency & Percentage & Category \\
\hline $\mathbf{1}$ & 30 & $96.77 \%$ & High \\
$\mathbf{2}$ & 28 & $90.32 \%$ & High \\
$\mathbf{3}$ & 6 & $19.35 \%$ & Low \\
$\mathbf{4}$ & 29 & $93.55 \%$ & High \\
$\mathbf{5}$ & 22 & $70.97 \%$ & Medium \\
$\mathbf{6}$ & 7 & $22.58 \%$ & Low \\
\hline
\end{tabular}

Table 2 shows that the students who are able to complete level 1 PISA questions are 30 out of 31 with a percentage of $96.77 \%$ included in the high category. This shows that almost all students are able to complete level 1 questions. This can be understood because the questions are still in a general context and are well known by students. The number of tudents who are able to complete level 2 PISA questions which are 28 out of 31with a percentage of $90.32 \%$. They are categorized in the high ability level. This means that almost all students could complete questions on level 2. This might be understood because the problem is still contains various information, so that students could solve it with a basic algorithm.

According to Table 2, the number of students who are able to complete level 3 PISA questions are 6 out of 31 with a percentage of $19.35 \%$ included in the low category. This means that almost all students have not been able to solve level 3 questions. This shows that students are still not carefully solving simple problems. There are 29 out of 31 students which are able to able to complete level 4 PISA questions with a percentage of $93.55 \%$. They are categorized in the high level. This fact indicates that almost all students can solve social level 4 questions. This shows that students are able to analyze real-world problems into mathematical form.

As can be seen in Table 2, there are 22 students out of 31were able to complete level 5 PISA questions with a 
percentage of $70.97 \%$. This group of students is categorized into the moderate level meaning that only some students are able to solve level 5 questions. This could be explained that the level 5 problems contains a complex situation with various obstacles in it so that some students might guesses the solution. Moreover, only 7 students out of 31 are able to complete PISA questions level 6 with a percentage of $22.58 \%$. This is categorized into the low level. This indicates that only a few students are able to complete level 6 questions. This might be due to the fact that the level 6 problems require complex conceptualization and generalization.

Table 3. Completion of High Ability Students by Level

\begin{tabular}{cccc}
\hline Level & Frequency & Percentage & Category \\
\hline 1 & 7 & $100 \%$ & High \\
\hline 2 & 7 & $100 \%$ & High \\
\hline 3 & 2 & $28.57 \%$ & Low \\
\hline 4 & 7 & $100 \%$ & High \\
\hline 5 & 7 & $100 \%$ & High \\
\hline 6 & 7 & $100 \%$ & High \\
\hline
\end{tabular}

Table 3 shows the level of completion by high ability students (there are 7 students, shown in Table 1) in solving PISA problems level 1 to 6 . It can be seen that the high ability students were able to complete all levels of problems except level 3. Only 2 students out of 7 (28.57\%) are able to solve the level three problems. This might be due to misunderstanding of the question.

Table 4 shows the completion level of the students with medium ability in answering question of problem level 1 to 6 . It can be seen that the medium ability students are able to complete all levels of problems except level 3 and 6. Both level 3 and 6 only 1 student out of 16 (6.25\%) are able to solve the level problems. This might be due to misunderstanding of the question and requires in-depth knowledge and understanding accompanied by technical mastery of mathematical operations, developing strategies, and new approaches to deal with new situations.

Table 4. Completion of Medium Ability Students by Level

\begin{tabular}{cccc}
\hline Level & Frequency & Percentage & Category \\
\hline 1 & 16 & $100 \%$ & High \\
\hline 2 & 15 & $93.75 \%$ & High \\
\hline 3 & 1 & $6.25 \%$ & Low \\
\hline 4 & 16 & $100 \%$ & High \\
\hline 5 & 14 & $87.5 \%$ & High \\
\hline 6 & 1 & $6.25 \%$ & Low \\
\hline
\end{tabular}

Table 5 shows students with low ability category who are able to complete PISA level 1 questions by 7 students with a percentage of $87.5 \%$ including the high category and this can be understood by most students are able to solve questions level 1 because it is still in a general context and easy to understand, and students who are able to complete level 2 PISA questions by 6 students with a percentage of $75 \%$ including the category of this medium indicate some students have been able to complete level 2 questions this can be understood because the questions can still be interpreted, and students who are able to complete level 3 PISA questions 3 students with a percentage of $37.5 \%$ are included in the low category. This shows that many students have not been able to solve level 3 problems. There may be errors in their problem solving strategies. students who are able to complete PISA level 4 questions are 6 students with a percentage of $75 \%$ included in the medium category this shows some students are able to solve level 4 questions which contains a concrete situation, students who are able to complete level 5 PISA questions are 1 student with a percentage of $12.5 \%$ included in the low category this shows that many students have not been able to complete level 5 questions and this can be understood because the questions which contains a complex situation with various obstacles in it so that allegations emerge in the solution, and students who are able to complete PISA questions level 6 as many as 0 students with a percentage of $0 \%$ included in the low category this shows all students in the low ability category are not able to solve questions level 6 this can be understood questions that require in-depth knowledge and understanding are accompanied by technical mastery of mathematical operations, developing strategies, and new approaches to deal with new situations. In general, it can be concluded that students with low ability are only able to solve PISA level 1 questions well.

Table 5. Completion of Low Ability Students by Level

\begin{tabular}{llll}
\hline Level & Frequency & Percentage & Category \\
\hline 1 & 7 & $87.5 \%$ & High \\
\hline 2 & 6 & $75 \%$ & Medium \\
\hline 3 & 3 & $37.5 \%$ & Low \\
\hline 4 & 6 & $75 \%$ & Medium \\
\hline 5 & 1 & $12.5 \%$ & Low \\
\hline 6 & 0 & $0 \%$ & Low \\
\hline
\end{tabular}

Table 6 presents the percentage of mathematical literacy ability indicators of students in solving PISA problem level 1 to 6 . As can be seen in Table 6, the highest percentage of indicators of the mathematical literacy abilities is communication skills with a percentage of $93.55 \%$ which shows high level achievement. This shows that most students have communication skills since this is the basis of mathematical literacy. The percentage of students who have mathematical abilities is $78.23 \%$. This is categorized as medium level. The number shows that some students are able to use mathematics in problem solving. They also have a similar ability to determine strategies to solve problems and ability to use operations and symbol languages, formal languages, and technical languages. 
Table 6. Percentage of Mathematical Literacy Ability Indicators

\begin{tabular}{cccccc}
\hline $\begin{array}{c}\text { Item } \\
\text { Question }\end{array}$ & Communication & Mathematizing & $\begin{array}{c}\text { Devising } \\
\text { Strategies for } \\
\text { Solving } \\
\text { Problems }\end{array}$ & $\begin{array}{c}\text { Reasoning } \\
\text { and } \\
\text { Argument }\end{array}$ & $\begin{array}{c}\text { Use Operations and } \\
\text { Language Symbols, } \\
\text { Formal and Technical } \\
\text { Languages }\end{array}$ \\
\hline $\mathbf{1}$ & 30 & - & - & 29 & - \\
\hline $\mathbf{2}$ & 31 & 27 & 27 & 27 & 27 \\
\hline $\mathbf{3}$ & 29 & - & - & 6 & - \\
\hline $\mathbf{4}$ & 31 & 28 & 28 & 28 & 23 \\
\hline $\mathbf{5}$ & 27 & 24 & 23 & 22 & 11 \\
\hline $\mathbf{6}$ & 26 & 18 & 11 & 10 & 89 \\
\hline Total & 174 & 97 & 89 & 122 & 71.77 \\
\hline $\begin{array}{c}\text { Percentage } \\
(\%)\end{array}$ & 93.55 & 78.23 & 71.77 & 65.59 & Medium \\
\hline Category & High & Medium & Medium & Medium & 28 \\
\hline
\end{tabular}

The percentage of $71.77 \%$ is in the medium category which indicates that the majority of students able to choose the right strategy and be able to use symbol operations in solving problems. In addition, the lowest indicator of mathematical literacy ability is reasoning ability and giving reasons with a percentage of $65.59 \%$ medium level). This shows that students are still not able to make reasoning and giving reasons that correspond to the questions given.

The students' mathematical literacy abilities in describing PISA content of change and relationship problems will be described based on written answers and student interviews. Students' written answers and interviews responding questions from PISA problems level 1 to 6 are presented as follows.

1. In 1998 the average height of young men and young women in the Netherlands is presented in the following graph.

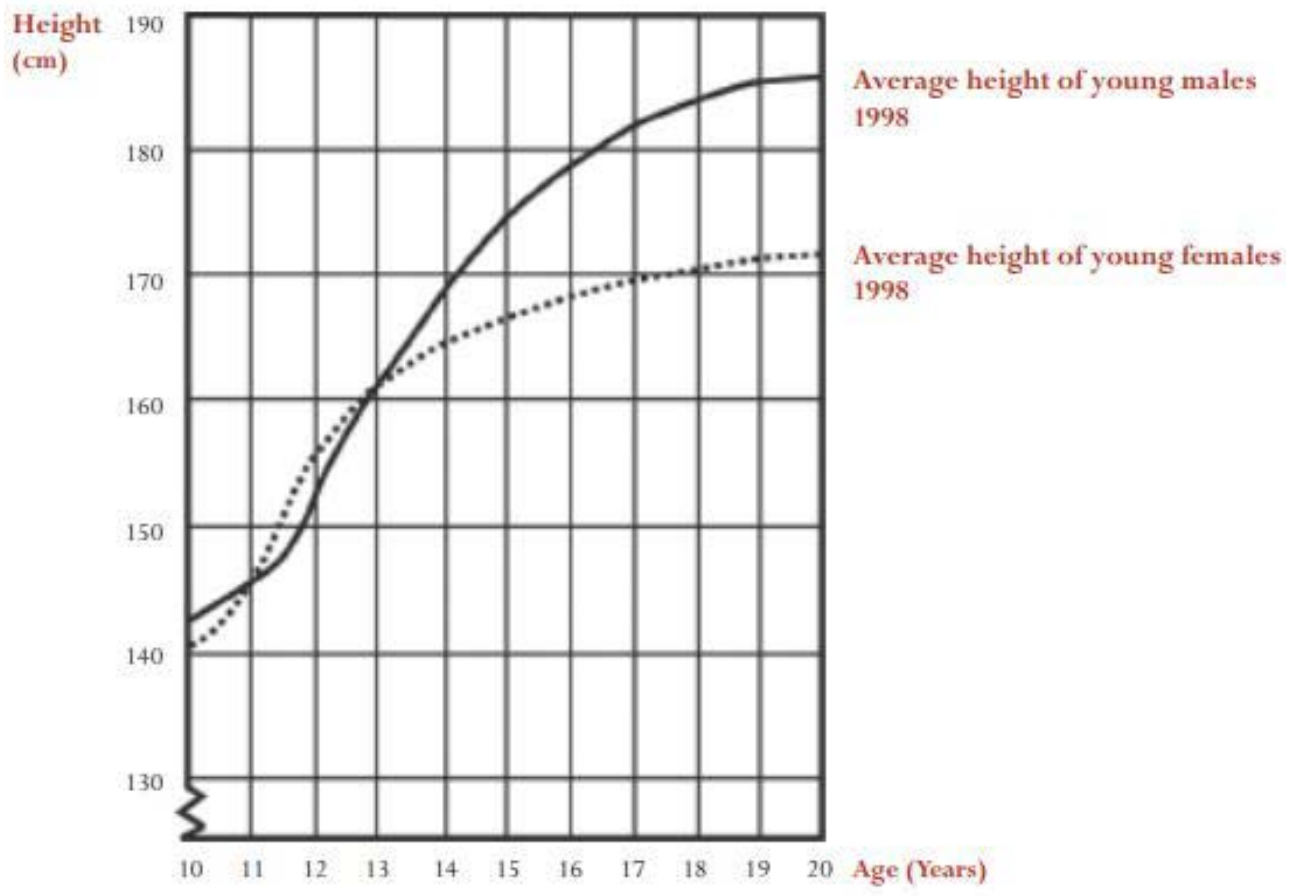


Based on the graph above, which period / interval shows young women higher than young men of the same age? (Source: PISA 2003 Level 1)

Student answers to question number 1

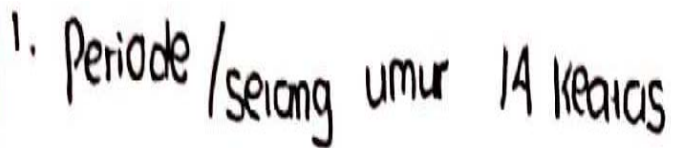

Figure 1. Results of Student Answer Question Number 1

Translated from student answer:

1. Period / interval of age above 14 years

The following are excerpts of interviews with students about the answers number 1 (R: researcher, S: student).

$\mathrm{R}$ : What do you understand from question number 1 ?

$\mathrm{S}$ : There is no.

$\mathrm{R}$ : Does that mean you also don't know the meaning of the problem?

$\mathrm{S}:$ Not.

$\mathrm{R}$ : Try reading the question again!
S : Based on the graph above, which period / interval indicates that adolescent girls are higher from young men of the same age?

$\mathrm{R}$ : Now what do you think is the problem in the matter?

$\mathrm{S}$ : The period that shows young women is higher than young men.

$\mathrm{R}$ : Why can your answer be obtained like this?

$\mathrm{S}$ : Do not know.

$\mathrm{R}$ : So what's the answer?

$\mathrm{S}$ : The answer is yes like this, period / interval age 14 and above.

The results of the subject's work show that the subject has not been able to solve problem number 1 with the level 1 of PISA framework. The subject is able to explain what is known and what is asked in the problem. But the subject has not been able to understand the purpose of the problem so it cannot solve the problem correctly.

2. In 1998 the average height of young men and young women in the Netherlands is presented in the following graph.




Since 1980 the average height of a 20 years old girl has been increased by $2.3 \mathrm{~cm}$ to a height of $170.6 \mathrm{~cm}$. What is the average height of the 20-year-old girl? (Source: PISA 2003 Level 2)

$\underline{\text { Student answers to question number } 2}$

$$
\begin{aligned}
& \text { 2) Diketanui : rata-rat: } 2,3 \mathrm{~cm} \\
& \text { trnggi baclan:1706 cm. } \\
& \text { Ditanya : rata-rata tinggi bodan ..? } \\
& \text { Dyamab: } 170.6 \mathrm{~cm}+2,3 \mathrm{~cm} \cdot 172.9 \mathrm{~cm} .
\end{aligned}
$$

Figure 2. Results of Student Answer Question Number 2

2. Translated from student answer:

Note: average $=2.3 \mathrm{~cm}$ height $=170.6 \mathrm{~cm}$

Asked: average height?

Answer: $170.6 \mathrm{~cm}+2.3 \mathrm{~cm}=172.9 \mathrm{~cm}$.

The following are excerpts of interviews with students about the answers number 2 (R: researcher, S: student).

$\mathrm{R}$ : What do you understand from question number 2 ?

$\mathrm{S}$ : The average height of young women who experienced an increase of $2.3 \mathrm{~cm}$.
$\mathrm{R}$ : Do you know the meaning of the problem?

$\mathrm{S}:$ Yes, I know.

$\mathrm{R}$ : Try to retell the problem!

S : In 1980 the average height of 20 year old girls increased by $2.3 \mathrm{~cm}$ towards $170.6 \mathrm{~cm}$ height.

$\mathrm{R}$ : What is the problem in the matter?

S : Average 20 year old girl's height.

$\mathrm{R}$ : So what's the answer?

$\mathrm{S}$ : So $170.6 \mathrm{~cm}+2.3 \mathrm{~cm}=172.9 \mathrm{~cm}$.

$\mathrm{R}$ : Why is it like this?

$\mathrm{S}$ : Because in my opinion to look for an average, height plus increase.

The results of the subject's work show that the subject has not been able to solve problem number 2 with the PISA level 2. The subject understands the problem proven subject writing is known and what is asked in the problem. But the subject was not right in writing the mathematical model. Furthermore, the subject begins to reason and plan to solve the problem, namely looking for a high average using mathematical operations, but the results of students' answers do not match what is asked in the problem.

3. In 1998 the average height of young men and young women in the Netherlands is presented in the following graph.

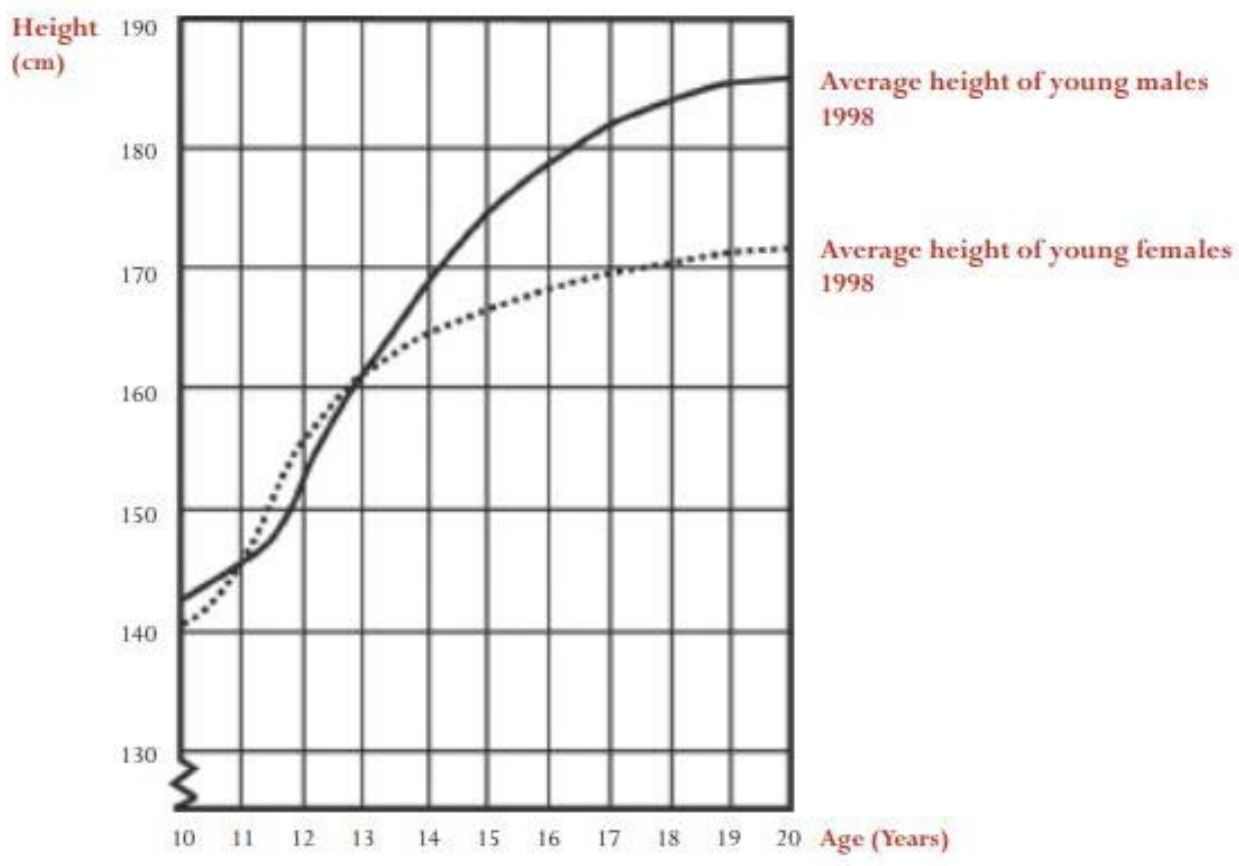

Explain why the graph showing the average growth of a woman's body is slowing after 12 years of age? (Source: PISA 2003 Level 3)

Student answers to question number 3



Figure 3. Results of Student Answer Question Number 3 
Translated from student answer:

3. Due to the growth of male height that has increased very drastically after the age of 12 years, so the average growth of female height has slowed.

The following are excerpts of interviews with students about the answers number 3 (R: researcher, S: student).

$\mathrm{R}$ : What do you understand from question number 3 ?

$\mathrm{S}$ : The graph shows the average height slowed after age 12 year.

$\mathrm{R}$ : Do you know what that means?

$S$ : Yes, i know.

$\mathrm{R}$ : Try to retell the problem!

$\mathrm{S}$ : Explain why the graph shows the average growth of a woman's height experience a slowdown after the age of 12 years?

$\mathrm{R}$ : What is the problem in the matter?

$\mathrm{S}$ : The reason why the average growth in women's height is slowing after age 12 year.

$\mathrm{R}$ : Why the answer can be like this?

$\mathrm{S}$ : Because it is seen from the graph also that the male's height growth has increased which is very drastic after 12 years of age so that a woman's height growth experiences slowing down.

The results of the subject's work show that the subject has not been able to solve problem number 3 with the PISA level 3. The subject has not understood the problem proven the subject does not write what is known in the problem. Furthermore, the subject has not been able to reason and provide the right reasons in solving the given problem.

4. Below are 3 towers that have different heights and are composed of two shapes, hexagon and rectangular shapes.
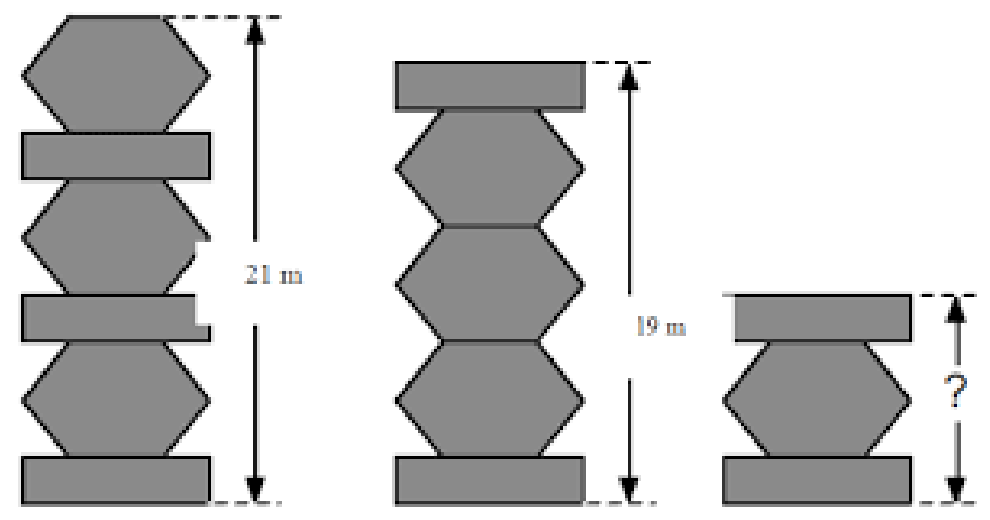

How tall is the shortest tower? (Source: PISA 2003 Level 4)

$\underline{\text { Student answers to question number } 4}$



Figure 4. Results of Student Answer Question Number 4 
Translated from student answer:

4. Note:

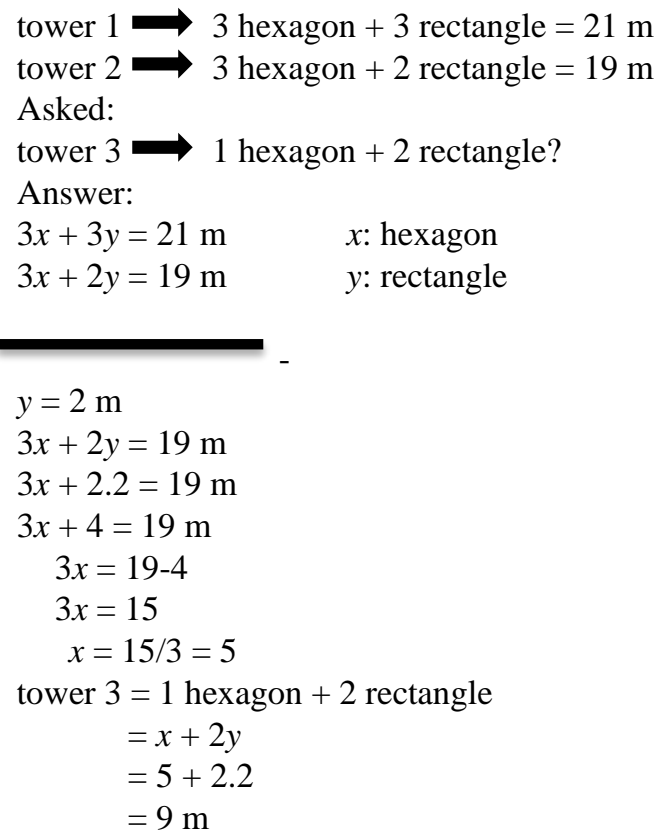

The following are excerpts of interviews with students about the answers number 4 (R: researcher, S: student).

$\mathrm{R}$ : What do you understand from question number 4 ?

S : Three towers that have different heights and are composed of 2 shapes.

$\mathrm{R}$ : Do you know what that means?

$\mathrm{S}$ : Yes, I know.

$\mathrm{R}$ : Try to retell the problem and what is the problem in the problem?

$\mathrm{S}$ : This is tower 1 , there are 3 rectangles and 3 hexagons, tower 2 has 2 rectangles same 3 hexagons and tower 3 that's 2 rectangles and 1 hexagon. Which was asked in the problem this look for tower height 3 .

$\mathrm{R}$ : Why is it like this?

$\mathrm{S}$ : Because hexagons are likened to $\mathrm{X}$ and $\mathrm{Y}$ is likened to rectangles constantly being sought eliminated equally substitution.

$\mathrm{R}$ : Why use the letters $\mathrm{X}$ and $\mathrm{Y}$ as symbols?

$S$ : Let it be easy.

$\mathrm{R}$ : So what's the answer?

$\mathrm{S}$ : Tower 1 that's $21 \mathrm{~m}$ high, tower 2 is $19 \mathrm{~m}$ high, then tower 3 consists of 1 hexagon and 2 rectangles continue to look for the height of the hexagon, how much is the same rectangle.

The results of the subject's work show that the subject is able to solve problem number 4 with the PISA level 4. The subject understands the problem proven subject writing is known and what is asked in the problem. The subject is able to write a mathematical model by using mathematical equations. Furthermore, the subject begins to reason and plan to solve the problem, namely finding the height of each hexagon and rectangle then looking for tower three. In addition, the subject is able to use several operations and symbols such as $x$ and $y$ in the process of solving the problem correctly.

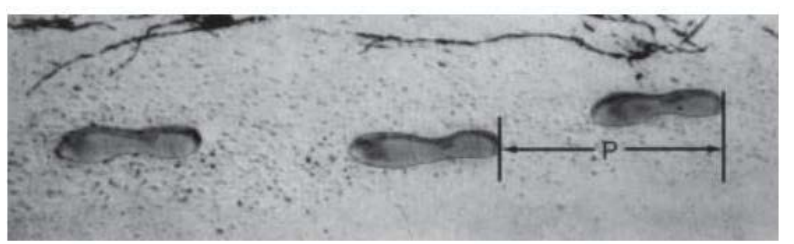

The picture above shows the footprints of a man who has walked. Pacelength / Length P is the distance between the back of the footprint.

For men, there is a formula that applies in estimating footprints where: $\frac{n}{p}=140$

$\mathrm{n}=$ number of steps per minute and

$\mathrm{p}=$ pacelength $(\mathrm{m})$

If the formula above applies to Heiko who is running at 70 steps per minute what is the length of Heiko's pacelength? Show your calculations! (Source: PISA 2003 Level 5)

\section{Student answers to question number 5}

$$
\text { 5. } \begin{aligned}
\frac{n}{p} & =140 \\
n & =70 \\
\frac{n}{p} & =140 \\
p & =\frac{n}{14: 0} \\
p & =\frac{70}{140} \\
p & =\frac{1}{2} \mathrm{~m}
\end{aligned}
$$

Figure 5. Results of Student Answer Question Number 5

The following are excerpts of interviews with students about the answers number 5 (R: researcher, S: student).

$\mathrm{R}$ : What do you understand from question number 5 ?

S : Heiko walked with 70 steps per minute.

$\mathrm{R}$ : Do you know what that means?

$\mathrm{S}:$ Yes, i know.

$\mathrm{R}$ : Try to retell the problem.

$\mathrm{S}:$ If the formula above applies to Heiko who is running at 70 steps per minute.

$\mathrm{R}$ : What is the problem in the matter?

$S$ : Heiko's pacelength length.

$\mathrm{R}$ : Why is it like this?

$\mathrm{S}$ : Because the formula is known like that.

$\mathrm{R}$ : From where?

$\mathrm{S}$ : From formula. 
$\mathrm{R}$ : So what's the answer?

$\mathrm{S}$ : Use the formula that is known from the problem. So, the answer $\frac{n}{p}=140, \mathrm{n}=70$,

$$
\mathrm{p}=\frac{n}{140}=\frac{70}{140}=\frac{1}{2} \mathrm{~m} \text {. }
$$

The results of the subject's work show that the subject is able to solve questions number 5 with the level 5 of PISA. The subject understands the problem proven subject writing what formula is known in the problem. The subject is able to write the mathematical model. Furthermore, the subject begins to reason and plan to solve the problem that is looking for a long leg (pacelength). In addition, the subject is able to use several operations and symbols in the process of solving the problem correctly.

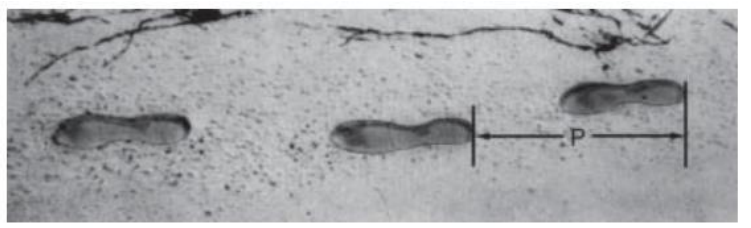

The picture above shows the footprints of a man who has walked. Pacelength / Length P is the distance between the back of the footprint.

For men, there is a formula that applies in estimating footprints where: $\frac{\boldsymbol{n}}{\boldsymbol{p}}=140$

$\mathrm{n}=$ number of steps per minute and

$\mathrm{p}=$ pacelength $(\mathrm{m})$

Bernard knew that the length of his foot length was 0.8 meters. The formula above also applies to him. Calculate the walking speed of Bernard's feet in meters per minute and in units of kilometers per hour. Show your calculations! (Source: PISA 2003 Level 6)

\section{$\underline{\text { Student answers to question number } 6}$}

$$
\begin{aligned}
& \text { 6. } \frac{n}{p}=140 \\
& =n=0.0 \cdot 140 \\
& \text { : } 112 \text { langlan/menil } \\
& =112.00 \mathrm{~m}=89,6 \mathrm{melir} / \mathrm{sm} \text { it } \\
& =\frac{89.6}{1000} \times 60=5,376 \mathrm{~km} / \mathrm{jam}
\end{aligned}
$$

Figure 6. Results of Student Answer Question Number 6

Translated from student answer:

6. $\frac{n}{p}=140$

$\mathrm{n}=0.8140$
$=112$ steps $/$ minute

$=1120.8=89.6 \mathrm{~m} /$ minute

$=\frac{89,6}{1000} \times 60=5.376 \mathrm{~km} /$ hour

The following are excerpts of interviews with students about the answers number 6 (R: researcher, S: student).

$\mathrm{R}$ : What do you understand from question number 6 ?

$\mathrm{S}$ : The length of the foot length is 0.8 meters.

$\mathrm{R}$ : Do you know the meaning of the problem?

$\mathrm{S}$ : Yes, I know.

$\mathrm{R}$ : Try to retell the problem!

$\mathrm{S}$ : Bernard know that the length of the foot length is 0.8 meters. The above formula also applies for himself.

$\mathrm{R}$ : What is the problem in the matter?

$\mathrm{S}$ : Bernard's walking speed is in meters per minute and in kilometers per unit hour.

$\mathrm{R}$ : From where? Why can be obtained like this?

$\mathrm{S}$ : From Bernard's foot length is $0.8 \mathrm{~m}$ multiplied by the formula above 140 so that it becomes 112 steps per minute.

$\mathrm{R}$ : So what's the answer?

S : The answer $\frac{n}{p}=140, \mathrm{n}=0.8 \times 140=112$ steps $/$ minute. Then 112 x $0.8=89.6 \mathrm{~m} / \mathrm{min}$. Then $89.6 / 1000 \mathrm{x}$ $60=5.376 \mathrm{~km} /$ hour.

The results of the subject's work show that the subject is able to solve problem number 6 with the PISA level, which is level 6 . The subject starts by writing what the formula is known in the problem. The subject writes a mathematical model and used several operations and symbols in the process of completion. Next the subject begins to reason and plan to solve the problem that is looking for speed.

Based on the results of the data analysis above and see in table 2, table 3, table 4 and table 5. Students as a whole are able to reach level 1 of $96.77 \%$ where high and medium ability students can complete $100 \%$ while low ability students only $87.5 \%$. Students are able to solve level 2 problems of $90.32 \%$ where high ability students can complete $100 \%$, medium ability students $93.75 \%$, and low ability students $75 \%$. Students are able to solve level 3 problems of $19.35 \%$ where high ability students complete $28.57 \%$, medium ability students at $6.25 \%$, and low ability students at $37.5 \%$. Students are able to solve level 4 problems of $93.55 \%$ where high ability students and medium ability students can complete 100\% while low ability students only $75 \%$. Students are able to solve level 5 problems of $70,97 \%$ where high ability students can complete $100 \%$, medium ability students at $87.5 \%$, and low ability students only $12.5 \%$. Finally, students are able to complete level 6 questions by $22.58 \%$ where high-ability students could complete $100 \%$, medium-ability students by $6.25 \%$, and low-ability students none are able to complete (0\%).

Furthermore, there will be a description of high, medium, and low ability students based on mathematical literacy indicators. 


\section{Students with High Ability}

Students with high abilities in questions 1 (level 1) to questions 6 (level 6) can meet the mathematical literacy indicator, namely communication skills. Evidenced by many students who can write or communicate what is known and what is asked according to the information contained in the problem. Problem 2 (level 2), question 4 (level 4), question 5 (level 5), and question 6 (level 6) can fulfill the second mathematical literacy indicator, namely mathematical abilities. Evidenced by the many highly capable students able to write and explain mathematical models in accordance with the questions given. Problem 2 (level 2), question 4 (level 4), question 5 (level 5), and problem 6 (level 6) can meet the third indicator of mathematical literacy, namely the ability to determine strategies to solve problems. Evidenced by the many highly capable students able to determine and use and explain strategies to solve problems correctly according to the information provided in the problem. Problem 2 (level 2), question 4 (level 4), question 5 (level 5), and question 6 (level 6) can fulfill the fourth indicator of mathematical literacy, namely the ability of reasoning and giving reasons. Evidenced by the many highly capable students able to write and explain solutions in accordance with the questions given along with how to obtain them. But many students on question number 3 (level 3) are still not right in providing solutions according to the questions given. This is in line with research Rusmining, et al. (2014) which states that communication skills, mathematical abilities, and the ability to form strategies to solve student problems are good, but the ability of reasoning and giving reasons to students is still low. Problem 2 (level 2), question 4 (level 4), question 5 (level 5), and question 6 (level 6) can fulfill the fifth mathematical literacy indicator, namely the ability to use operations and symbol languages, formal languages, and technical languages. Evidenced by the many highly capable students able to use symbolic languages such as arithmetic operations, formal and technical languages correctly in solving problems according to the questions given. This is supported by research by Oktiningrum et al. (2018) which states that students with high abilities are very good at identifying problems in questions and interpreting them in mathematical models, numbers, and symbols. This ability allows students to complete the questions given and make reasonable reasons in their conclusions.

\section{Students with Medium Ability}

Students with medium category abilities in questions 1 (level 1), questions 2 (level 2), questions 4 (level 4), and questions 5 (level 5) can fulfill several indicators of mathematical literacy, namely communication skills, mathematical abilities, abilities to determine strategy to solve problems, the ability to reason and give reasons, and the ability to use operations and language symbols, formal language, and technical language. Evidenced by the results of the test many capable students are able to write or communicate what is known and what is asked according to the information contained in the problem, able to write and explain mathematical models, able to determine and use and explain strategies to solve problems correctly, able to write and explain the solution and how to obtain it, and able to use symbolic languages such as arithmetic operations, formal and technical languages correctly in solving problems according to the problems given. But in problem 3 (level 3) some students cannot fulfill the reasoning ability because they have not been able to write and explain solutions and how to obtain them and give reasons and questions number 6 (level 6) some students cannot determine the mathematical model correctly so that it does not meet the mathematical ability. This causes other indicators such as the ability to determine strategies to solve problems, the ability to reason and give reasons, and the ability to use operations and language symbols, formal language, and technical language are not fully met. This is supported by Stacey's research (2011) in his research that there is a statement that in mathematical literacy the most important is mathematical modeling and its component processes. The mathematical process is related to formulating the problem so that it can be solved then the mathematical solution can be interpreted to provide answers to these mathematical problems. This is also supported by research by Oktiningrum et al. (2018) which states that students with moderate abilities can identify information, but students are less able to use mathematical symbols and instruments. The mathematical process is related to formulating the problem so that it can be solved then the mathematical solution can be interpreted to provide answers to these mathematical problems.

\section{Students with Low Ability}

Students with low category abilities are less optimal in solving problems. It is proven that many students in questions 1 (level 1) to questions 6 (level 6) only have communication skills while for other mathematical literacy they do not fulfill the whole. This is supported by research by Oktiningrum et al. (2018) which states that students with low abilities are quite able to identify problems, deficiencies in the ability to find strategies and low in other mathematical literacy abilities.

Based on the above research it can be seen that high ability students can meet the five indicators of mathematical literacy, namely communication skills, mathematical abilities, abilities to determine strategies for problem solving, reasoning and reasoning abilities, and the ability to use operations and symbols languages, formal languages, and technical languages. . Medium able students can fulfill mathematical literacy indicators well, 
namely communication skills but on other indicators namely, mathematical abilities, ability to determine strategies to solve problems, reasoning and reasoning abilities, and ability to use operations and symbolic languages, formal languages, and technical languages are still less than optimal. While some low-ability students have not been able to use the five indicators of mathematics literacy. In line with the research of Putri, et al. (2015) which concludes that high ability students have optimal skills in controlling and solving every problem. Moderately capable students are good enough to control and solve every problem even though in some problems moderate abilities students are less optimal in using their abilities. Low ability students have less optimal skills in controlling and solving problems. Moderately capable students are good enough to control and solve every problem even though in some problems moderate abilities students are less optimal in using their abilities. Low ability students have less optimal skills in controlling and solving problems. Moderately capable students are good enough to control and solve every problem even though in some problems moderate abilities students are less optimal in using their abilities.

Seen from table 6 that presents the percentage indicators of mathematical literacy ability. The highest indicators of mathematical literacy are communication skills with a percentage of $93.55 \%$, then mathematical abilities with a percentage of $78.23 \%$, the ability to determine strategies to solve problems and the ability to use operations and symbolic languages, formal languages, and technical languages Have the same percentage of 71, $77 \%$. Meanwhile, the lowest indicator of mathematical literacy ability is reasoning ability and giving reasons with a percentage of $65.59 \%$. From the explanation, it can be seen that the ability most students have is communication skills, while the abilities that are not widely owned by students are mathematical abilities, reasoning abilities and giving reasons, and the ability to determine strategies to solve problems. This is in line with the results of research Rusmining, et al. (2014) which concludes that in the process of mathematical literacy, mathematical abilities, reasoning abilities and reasoning, and the ability to determine strategies to solve problems are considered lower than other aspects.

\section{Conclusions}

Based on the description above, it can be concluded that high ability students can well fulfill the five indicators of mathematical literacy, namely communication skills, mathematical abilities, abilities to determine strategies for problem solving, reasoning and argument abilities, and abilities to use operations and symbols languages, formal languages, and technical languages. Medium ability students can fulfill mathematical literacy indicators well, namely communication skills but have not been maximized in other indicators namely, mathematical abilities, abilities to determine strategies for problem solving, reasoning and reasoning abilities, and ability to use operations and symbolic language, formal language, and technical language. However, low ability students are not optimal in using the five indicators of mathematics literacy.

\section{REFERENCES}

[1] Abdurrahman, Mulyono. Pendidikan Bagi Anak Berkesulitan Belajar; PT Rineka Cipta, Jakarta, 2010.

[2] Ahyan, S., Zulkardi, Z., and Darmawijoyo, D. Developing Mathematics Problem Based on PISA Level of Change and Relationships Content, Journal on Mathematics Education, 5(1), 47-56, 2014.

[3] Amir, Zubaidah, and Risnawati. Psikologi Pembelajaran Matematika; Aswaja Pressindo, Yogyakarta, 2016.

[4] Arifin, Zainal. Evaluasi Pembelajaran; PT Remaja Rosdakarya, Bandung, 2011.

[5] Arikunto, Suharsimi. Prosedur Penelitian Suatu Pendekatan Praktis; PT. Rineka Cipta, Jakarta, 2012.

[6] Arseven, A. Mathematical Modelling Approach in Mathematics Education, Universal Journal of Educational Research, 3(12), 973-980, 2015.

[7] Murdaningsih, S., and Murtiyasa, B. An Analysis on Eight Grade Mathematics Textbook of New Indonesian Curriculum (K-13) Based on Pisa's Framework, Journal of Research and Advances in Mathematics Education, 1(1), 14-27, 2016.

[8] Murtiyasa, B., Rejeki, S., \& Setyaningsih, R. PISA-like problems using Indonesian contexts, In Journal of Physics: Conference Series. IOP Publishing, Vol. 1040, No. 1, 2018.

[9] Nizar, H., \& Putri, R. I. I. Developing PISA-LIKE Mathematics Problem Using The 2018 Asian Games Football and Table Tennis Context, Journal on Mathematics Education, 9(2), 183-194, 2018.

[10] Novita, R., \& Putra, M. Using Task Like PISA’s Problem to Support Student's Creativity in Mathematics, Journal on Mathematics Education, 7(1), 31-42, 2016.

[11] OECD 2010 PISA, Mathematics Framework: Draft Subject to Possible revision after the Field Trial, 2012.

[12] OECD, Programme for International Student Assessment: PISA Results 2015, 2017.

[13] Ojose, B. Mathematics literacy: Are we able to put the mathematics we learn into everyday use, Journal of Mathematics Education, 4(1), 89-100, 2011.

[14] Oktiningrum, W., Zulkardi, Z., and Hartono, Y. Developing PISA-LIKE Mathematics Task with Indonesia Natural and Cultural Heritage as Context to Assess Student's Mathematical Literacy. Journal on Mathematics Education, 
7(1), 1-8, 2016.

[15] Putri, Riandani Sarwindah, Susanto, and Dian Kurniati. Analisis Keterampilan Metakognitif Siswa dalam Menyelesaikan Masalah Matematika Berbasis Polya Subpokok Bahasan Garis dan Sudut Kelas VII-C di SMP Negeri 1 Genteng Banyuwangi, Artikel Ilmiah Mahasiswa, 2(1), 1-7, 2015.

[16] Rusmining, Waluyo, S.B., and Sugianto. Analysis of Mathematics Literacy, Learning Constructivism and Character Education, International Journal of Education and Research, 2(8), 2014.

[17] Setiawan, H., Dafik, D., and Lestari, N. D. S. Soal Matematika Dalam PISA Kaitannya dengan Literasi Matematika dan Kemampuan Berpikir Tingkat Tinggi, In Prosiding Seminar Nasional Matematika Universitas Jember, 224-251, 2014.

[18] Stacey, K. The PISA View of Mathematical Literacy in Indonesia, Journal on Mathematics Education, 2(2), 95-126, 2011.

[19] Steen, L. A. Mathematics and democracy: The case for quantitative literacy, NCED, 2001.

[20] Sugiyono, Memahami Penelitian Kualitatif; Alfabeta CV, Bandung, 2016.

[21] Undang-Undang No. 20 tentang Sistem Pendidikan Nasional; Depdiknas, Jakarta, 2003.

[22] Lin, S. W., and Tai, W. C. Latent Class Analysis of Students' Mathematics Learning Strategies and the Relationship between Learning Strategy and Mathematical Literacy, Universal Journal of Educational Research, 3(6), 390-395, 2015.

[23] Wijaya, A. Student's Information Literacy: A Perspective from Mathematical Literacy, Journal on Mathematics Education, 7(2), 73-82, 2016.

[24] Wulandari, N. F. Mathematics Skill of Fifteen Years Old Students in Yogyakarta in Solving Problems Like PISA, Journal on Mathematics Education, 9(1), 129-144, 2018. 